\title{
The Roots of Judicial Review in Hungary
}

In 1848, during the initial phase of the Hungarian Revolution, the Parliament approved a reform package called "April Laws" thereby transforming the feudal-representative monarchy into a constitutional one. The aim of this legislation was to reform the entire legal system, and to make all necessary changes for the new economic and political system.

Following the suppression of the Revolution in 1849, the Habsburgs established an absolutistic regime that lasted until 1860. The Hungarian historical constitution was suspended, and the entire country was divided into 5 provinces treated as territories of the Austrian Empire, and because of that, step-by-step the entire Austrian legal system was introduced in Hungary. As the international political crisis deepened in the late 1850s, Emperor Franz Joseph decided to restore Hungary's constitutionality. The question was inevitable: which legal norms were in force? Were these the ones in use before the Revolution, the Acts made by the legislation in 1848, or the Austrian legal system as a whole?

In 1848, during the initial phase of the Hungarian Revolution, the Hungarian Parliament approved a reform package called "April Laws", transforming the feudal-representative monarchy into a constitutional one. ${ }^{1}$ The aim of this legislation was to reform the entire legal system, and to make all the necessary changes for a new economic and political system. Under the historical circumstances -mostly because of the tense political situation- the last "feudal" 2 Diet only had the opportunity to amend the most urgent Acts; which is why the April Laws could not be considered as a whole Constitution. ${ }^{3}$ The adoption of these Acts, which passed the vote in both houses of the legislative assembly, and were granted the royal assent to by King Ferdi-

\footnotetext{
${ }^{1}$ ECKHART, Magyar alkotmány- és jogtörténet 418.

${ }^{2}$ This phrase indicates - in the Hungarian legal history - the era between 1000 (the foundation of the Christian state) and 1848, when the revolution took place. See: MEZEY, Magyar jogtörténet 10.

${ }^{3}$ MEZEY, Magyar alkotmánytörténet 244-245.
}

nand $\mathrm{V} ., 4,5$ could be characterized as a reform from a strictly legal perspective - even if the events that followed during 1848-1849 have ultimately led to a revolution and a war for independence.

These laws, in essence, set up the following system: a Hungarian government shall be established which was to be responsible to the Parliament in Budapest; said Parliament - based on popular representation - was to replace the feudal Diet previously seated in Pressburg. The suffrage was based on wealth and certain basic rights; among them the freedom of the press, were also guaranteed. The biggest change in the economic system was the abolishment of the nobility's tax exemption. Feudalism ended by abolishing the so-called robot - that is the labor owed by the serfs to their landlords. ${ }^{6}$ A law made it obligatory to liberate all serfs; and enti-

\footnotetext{
${ }^{4}$ Also called Emperor Ferdinand I. of Austria.

${ }^{5}$ ECKHART, Magyar alkotmány- és jogtörténet 420.

${ }^{6}$ MezeY, Magyar alkotmánytörténet 246-247.
} 
tle them to land ownership - whilst imposing a duty on the state to compensate the landowners. Some of the legal norms found in the April Laws (mostly the ones regarding the field of civil law) could be described as provisional and/or declarative. ${ }^{7}$ A good example for that is the law $^{8}$ that ordered the newly formed national assembly to adopt a new Civil Code, which would no longer have been based on the entailment - the most important legal institution characteristic of the medieval Hungarian civil law that substantially restricted the alienation of the land owned by nobilities. The roots of this legal institution can be found already in those rules and regulations that existed prior to the Hungarian settlement. ${ }^{9}$ The purpose of the entailment was to protect the unity of the property belonging to one (noble) clan. Since all relatives of the landholder were entitled to inherit the estate, their prior consent was required for its alienation in whole or in part. The challenges involved for the individual landholder in obtaining this consent - particularly from distant cousins, minors and unborn made it almost impossible to ensure that any transaction was successful. Any of the relatives could challenge such actions and render it void through his or her protest. ${ }^{10}$ In addition, the neighbors also had the right of preemption, and even the King had to approve such transactions. This is why by the $19^{\text {th }}$ century it had already become one of the greatest obstacles blocking the economic changes.

During the Spring of 1848, the abolishment of entailment was of highest priority but the legislators were well aware that the adoption of a new Civil Code (that would have changed the very foundations of the entire Hungarian civil law) could not happen overnight. This is why

\footnotetext{
${ }^{7}$ MeZeY, Magyar jogtörténet 156.

${ }^{8}$ See: Act Nr. 15 of 1848

9 TARJÁN, Nagy Lajos király kihirdeti az ősiség törvényét

${ }^{10}$ MezeY, Magyar jogtörténet 98.
}

the April Laws only stated the theory that entailment was to be abolished, and left it to the new Parliament to adopt the Civil Code that would have detailed its practical realization. For the time being, a juridical recess was ordered in all cases affected by this change. This was also supported by the politicians, who thought that the Parliament - which would have convened after the democratic elections - should have decided on such issues. ${ }^{11}$ The new democratic Parliament however, never got the chance to adopt these laws. In September of 1848, after successfully suppressing the uprisings in the entire Habsburg Empire except Hungary, King Ferdinand V. began to question the validity of the April Laws. Ferdinand V. wanted to dissolve the Parliament and appoint a new cabinet, which is why he refused to participate in the lawmaking from then on.12 A month later, the war for independence broke out between Hungary and the Habsburgs. ${ }^{13}$ In December 1848, King Ferdinand V. abdicated the throne to allow his nephew, Franz Joseph to succeed him. However, according to the Hungarian laws, ${ }^{14}$ the King should have asked for the affirmation of the Parliament to make such an action, therefore, the rule of Franz Joseph was not formally accepted until $1867 . .^{15}$

The situation became even more complicated following the suppression of the Revolution in August 1849, when the Habsburgs established an absolutistic regime that lasted until 1860. The Hungarian historical constitution was suspended, and the entire country was divided into five

\footnotetext{
${ }^{11}$ RÁTH, Az országbírói értekezlet a törvénykezés tárgyában 52 .

${ }^{12}$ ECKHART, Magyar alkotmány- és jogtörténet 422.

${ }^{13}$ N.b.: the word 'independence' refers to the Hungarians' aim to preserve their rights in the Habsburg Empire and does not include a will to separate from it. See: MEZEY, Magyar alkotmánytörténet 246.

${ }^{14}$ BeKe-MARTOS, Az Osztrák Császárság 101.

${ }^{15}$ See: BEKE-MARTOS, Állami legitimációs eljárások 6473.
} 
provinces treated as territories of the Austrian Empire. ${ }^{16}$ The Parliament was dissolved, so were the municipalities, and the courts were newly organized on the grounds of the Austrian model. ${ }^{17}$ Though the Viennese government supported the economic transition, it consequently denied the acceptance of the April Laws, which served as the basis of the constitutional monarchy and paved the way towards the modern capitalistic regime. ${ }^{18}$ Nevertheless, even if they had accepted these laws, the main problem would have remained: the laws, that would have allowed the definitive transformation, had not yet been adopted.

After the suspension of the Hungarian historical constitution one of the main goals of the Austrian government was the unification of the legal system. Therefore, the Austrian Criminal Code replaced the Hungarian medieval criminal laws, and the Austrian rules of procedure were introduced also. The biggest problem was that with the abolishment of the entailment, practically no applicable civil laws remained. ${ }^{19}$ The legislation of 1848 granted a juridical recess regarding all affected cases, but this solution was not sustainable for a longer period. ${ }^{20}$ In addition, the abolishment of entailment also brought about the disestablishment of a regulated line of inheritance, so it became inevitable to address this issue. The emperor issued the letters patent in 1852, which abolished the barriers of alienating property, and also put an end to the distinction between the regulation of lands owned by nobilities or non-noble individuals. ${ }^{21}$

In 1853 the Austrian Civil Code (ABGB) came into effect in Hungary, so step by step the entire

\footnotetext{
${ }^{16}$ MEZEY, Magyar alkotmánytörténet 253-255.

${ }^{17}$ MeZeY, Magyar alkotmánytörténet 428.

${ }^{18}$ MezeY, Horváth Boldizsár az országbírói értekezleten 33.

${ }^{19}$ KECSKEMÉTHY, Vázlatok egy év történetéből 26.

${ }^{20} \mathrm{RÁTH}, \mathrm{Az}$ országbírói értekezlet a törvénykezés tárgyában 34 .

${ }^{21}$ MezeY, Magyar jogtörténet 157.
}

Austrian legal system was introduced. A situation like this wasn't entirely unprecedented, because under the rule of Joseph II. something similar had already happened: he refused to be crowned the King of Hungary, because he did not want to be bound by the Hungarian Laws, which in his interpretation would have entitled him to change laws without the consent of the Parliament. Between 1780 and 1790, only the organization of the courts and the rules of proceedings were changed. In contrast, the changes after 1849 were much more substantial. Some of these legal norms (particularly in the area of civil law) were much more advanced than their former Hungarian counterparts. They have even introduced new legal institutions, like the modern land register, which has not existed at all before 1855 . The citizens started to enter into their contracts and prepare their last wills according to these regulations, and the judges were forced to base their rulings on these laws.

As the international political crisis deepened in the late 1850s, Emperor Franz Joseph decided to restore Hungary's constitutionality. He issued a new constitution, the October Diploma, in 1860. This stated that every former Hungarian state organization (including the Parliament, the municipalities, and the courts) should be restored, but it did not say anything about the applicable law. ${ }^{22}$ The question, however, was inevitable: which legal norms were in force? Were these the ones in use before the Revolution, the Acts made by the legislation in 1848, or the Austrian legal system as a whole?

The emperor first attempted to answer this question when he decided to convene the Parliament. In his ordinance he specifically stated that according to his intentions, only a few Acts of the April Laws would remain in effect (like the one that abolished the fiscal immunity of noblemen). This document was sent to the Judex Curiae (the

\footnotetext{
${ }^{22}$ SZABAD, Forradalom és kiegyezés válaszútján 160.
} 
Presiding Judge of the newly reorganized Hungarian Royal Curia - the highest ranking Court in the country), who was also ordered to organize a debate over the "organization of the adjudication". ${ }^{23}$ The emperor declared that every Austrian Act should remain in effect until the (Hungarian) Parliament changes them. ${ }^{24}$

To fulfill this request, a Commission was organized in 1861, the members of which were highranking judges and lawyers. The official duty of this forum was to decide on the "organization of the adjudication" but the content of this term was strongly debated..$^{25}$ The narrow interpretation would have only meant a proposal for the reorganization of the court system;26 while the broader content would have also entailed the validity-evaluation of all Austrian laws which had previously entered into force. The situation was getting more complicated by every passing day, because most of the municipalities declared the Austrian laws unconstitutional, ${ }^{27}$ and their newly reorganized courts started to base their rulings upon the old Hungarian laws. ${ }^{28}$ For the Habsburg-regime however, this was completely unacceptable since it only recognized laws used before the Revolution.

The starting point for the Commission was to return to the state of April 1848. There were a few problems stemming from the laws used before Revolution, for example, differentiated between noblemen and serfs - both in criminal and the civil laws. It seemed impossible for the most part to revert to these laws without substantial changes. Certain members thought this

\footnotetext{
${ }^{23}$ RÁTH, Az országbírói értekezlet a törvénykezés tárgyában 1 .

${ }^{24}$ KECSKEMÉTHY, Vázlatok egy év történetéből 64.

${ }^{25}$ RÁTH, Az országbírói értekezlet a törvénykezés tárgyában 8 .

${ }^{26}$ RÁTH, Az országbírói értekezlet a törvénykezés tárgyában 16.

${ }^{27} \mathrm{RÁTH}, \mathrm{Az}$ országbírói értekezlet a törvénykezés tárgyában 5 .

${ }^{28}$ SZABAD, Forradalom és kiegyezés válaszútján 160.
}

an easily solvable issue; because the regulations which had previously related to noblemen could have been applied to the emancipated serfs as well (this idea had already been used in the revolution of 1848). ${ }^{29}$ Another problem was that the abolishment of entailment also eliminated the basis of the medieval civil law. If the Commission, or later the Parliament had returned to this stage of legal development where the feudal law no longer existed but no new system had been developed, the judges would have received discretionary powers in most cases due to the lack of applicable law. Some suggested that the extension of the juridical recess imposed in the April Laws would have solved this conflict, not many supported this however.

The biggest obstacle nevertheless, was that the Austrian legal norms which had already been in effect for over 10 years in 1860, have introduced many important legal institutions, (for example the modern land registry in 1855), that had not existed in the medieval law, and the annulment of which would have caused an economic disaster. This seemingly left two possible options open: the Commission could have advised the Parliament to acknowledge the Austrian laws as being constitutional, or could have pushed for a return to the state of 1848, ignoring all the drawbacks mentioned earlier. The prior option was completely unacceptable for political and professional reasons alike. (It has been cited for example that the Austrian Criminal Code was too harsh, and the judicial processes took more time based on the Austrian rules of procedure.) $)^{30}$ The latter option was also problematic which is why some members of the Commission opted for a third solution, a compromise between these two.

\footnotetext{
${ }^{29}$ RÁTH, Az országbírói értekezlet a törvénykezés tárgyában 13-18.

${ }^{30} \mathrm{RÁTH}, \mathrm{Az}$ országbírói értekezlet a törvénykezés tárgyában 38-40.
} 
The members aiming for the third option argued that a distinction shall be made between public and private law. In the prior field it would have been unacceptable to let any Austrian laws remain in effect, because everything that happened before 1849 had been forced upon the country and had therefore been unconstitutional. Whenever there was a revolution, it was the normal reaction that the public law followed the changes in the political system. ${ }^{31}$ After the suppression of the 1848-1849 Revolution, the Habsburg forced their constitution on Hungary, creating an absolutistic regime - which is why everyone should have opposed anything that would have been less than the return to the basis of the April Laws. In the field of private law however, these rules could not be applied in the same way.

Both Ferenc Deák, and Boldizsár Horváth ${ }^{32}$ argued, that the main goal and principle of civil law is to protect the rights of the individuals, so they must be cautious with this issue. ${ }^{33}$ They said that all of those legal relations that had originated from the basis of the Austrian legal norms should then, in effect, have been evaluated and judged on those bases. In addition they claimed that until the Parliament would be capable of making laws, certain Austrian legal norms should be kept in effect, because their abolishment would be for the disadvantage of the individuals. (This could happen because both the October Diploma and the February Patent treated Transylvania and Croatia as separate countries ${ }^{34}$ and the legislators did not want to adopt any laws until the integrity of Hungary has been completely restored.)

\footnotetext{
${ }^{31}$ RÁTH, Az országbírói értekezlet a törvénykezés tárgyában 32-33.

${ }^{32}$ For more information see: KENYERES, Magyar Életrajzi Lexikon

${ }^{33} \mathrm{RÁTH}, \mathrm{Az}$ országbírói értekezlet a törvénykezés tárgyában 33-36.

${ }^{34}$ ECKHART, Magyar alkotmány- és jogtörténet 427.
}

The advocates of the compromise thought that legal security was just as valuable a principle as that of legality, and therefore, if they restored the state of 1848 , such an action would be unconstitutional because it would create a jurisdictional anarchy. ${ }^{35}$ What they could not have known was that the Parliament has only started to exercise its right to adopt new laws from 1867, when the Austro-Hungarian Compromise consolidated the relations between Austria, Hungary and the Habsburgs. That also meant that six years had passed without any result in lawmaking. ${ }^{36}$

In its proposal, the Commission wrote that the Hungarian civil laws should be applied - but in those cases where they would not be applicable (e.g. the Act abolishing the entailment) the courts should base their judgments on the transitory rules set up by the Commission for such purposes. This collection was called the Transitional Rules of Adjudication, and its propositions could be divided into three main categories: in some cases they introduced the old Hungarian legal norms (that was the case with the Bankruptcy Act or with the criminal laws), in other cases they modified the former Hungarian laws (like in law of succession or of family law), and - perhaps most importantly - they acknowledged that some of the Austrian legal norms should stay in force (like the ones introducing the land register, and resolving the legal relations between the noblemen and their former serfs).

Following the issuance of the Commission's proposal, a Committee was established by the House of Representatives, which proposed to accept these transitional rules without changes. After a debate, the representatives adopted it, as did the House of Lords. A few days later, the Hungarian Royal Curia ordered the courts to

\footnotetext{
${ }^{35}$ RÁTH, Az országbírói értekezlet a törvénykezés tárgyában 34.

${ }^{36}$ MEZEY, Magyar jogtörténet 158.
} 
base their rulings on the basis of said rules. ${ }^{37}$ As a consequence, many Austrian legal norms remained in effect, thanks to the judges, who based their decisions in civil law cases on the Austrian Civil Code, when they could not find any applicable laws. In my opinion, the Commission made a wise decision - even if that seemed the only real option.

\section{Conclusion:}

The most important (and so far left unanswered) question regarding the Commission of 1861 was exactly what this forum conducted as an activity; a Commission, whose status was hard to determine from a constitutional law perspective. It received its mandate from the King, who ordered the members to discuss the organization of adjudication and make recommendations relating thereto. ${ }^{38}$ Among the members was the Judex Curiae, who was the Chief Justice of Hungary at that time, and the appointed judges of the Hungarian Royal Curia as well as other invited individuals, mainly lawyers and legal scholars. The fact that only the 60 most reputable lawyers of the country were invited to the Commission shows its real significance. ${ }^{39}$

During the sessions, the members argued about two main issues: the organization of a court system (including the Curia) that should be set up, and about the law that these courts should apply. Regarding the first matter, the court system that had existed prior to 1848 was restored based on the recommendation of the Commission. ${ }^{40}$ The members decided similarly regarding the validity - or more precisely the constitutionality - of the Austrian laws: they deemed the

\footnotetext{
${ }^{37}$ MEZEY, Magyar jogtörténet 159.

${ }^{38}$ KECSKEMÉTHY, Vázlatok egy év történetéből 63-64.

${ }^{39}$ MezEY, Horváth Boldizsár az országbírói értekezleten 33.

${ }^{40} \mathrm{RÁTH}, \mathrm{Az}$ országbírói értekezlet a törvénykezés tárgyában 60-61.
}

state of 1848 as the standard. ${ }^{41}$ The reason for this decision was that according to the laws of 1790/1791 - that summarized the most important rules of the feudal constitution - the King was entitled to legislate but only together with the Parliament, and he could only issue decrees (letters patents) with content that was in accordance with the Acts.42 After 1850, the Viennese government however, introduced Acts and Codes foreign to the Hungarian legal traditions in an absolutistic manner (that is without calling the Parliament together). ${ }^{43}$ Such a severe breach of the legislative procedure would today be deemed void from a public law perspective, and according to the practice of the Constitutional Court, it would surely lead to the nullification of the law. ${ }^{44}$ Because of this role, we are here facing an organ that acted with the authority of judicial review, ${ }^{45}$ that evaluated the constitutionality of the laws based on the (historical) constitution's regulation on the legislative process.

Regarding those (Austrian) laws of which the validity was maintained temporarily, the members supported their action with legal security and the need to provide the security of the property and ownership of the private individuals. The Constitutional Court, even today, often uses the tool of setting a moratorium for the Parliament in order to have it change the unconstitutional norm and guarantee legal security. ${ }^{46}$ We nevertheless need to take into consideration that the Commission did not exclusively act as a "negative" legislative forum, since apart from

\footnotetext{
${ }^{41}$ RÁTH, Az országbírói értekezlet a törvénykezés tárgyában 58 .

${ }^{42}$ See: Act Nr. 12 of 1790/1791

${ }^{43}$ RÁTH, Az országbírói értekezlet a törvénykezés tárgyában 11, 20.

${ }^{44}$ KUKORELLI, Alkotmányjog 111-113.

${ }^{45}$ SZABÓ, Jogállami forradalom és a büntetőjog alkotmányos legitimitása

${ }^{46}$ SólyOM, Az alkotmánybíráskodás kezdetei Magyarországon 376-377.
} 
rendering the Austrian laws ineffective, it more than once also amended those rules and regulations. When it comes to a forum exercising the authority of judicial review no positive legislation is possible since that would mean taking over the duties of the legislature. In my opinion, however, and taking the historic circumstances into consideration, it is understandable why this Commission could and did amend the existing laws, because only the uncertainty was palpable surrounding the convening and operation of the Parliament and without an adequate reorganization of the laws a jurisdictional anarchy could have easily come about in the country. ${ }^{47}$ This is why the Commission first modernized the content of the earlier Hungarian laws (e.g. they eliminated the differences between noble and non-noble individuals which can be seen as adherence to a constitutional requirement), and they have also redrafted those parts of the Austrian laws that were not in compliance with the Hungarian legal traditions. During the debates, the question of what the mandate of the Commission includes has been repeatedly raised, and the members have often emphasized that legislation was the duty of the Parliament which they could not take over.

Based on its activity, I believe, that the Commission was a forum with the authority of judicial review and can therefore be considered as a predecessor of a constitutional court. It acted, on the one hand, as a control over the executive power, which had aimed at solving the above mentioned issue by upholding the validity of the Austrian laws. On the other hand, the fact that this forum debated the relationship of the Hungarian and Austrian laws with a consequent consideration for the principles of legal security and legality proves that the roots of the Hungar-

\footnotetext{
${ }^{47}$ RÁTH, Az országbírói értekezlet a törvénykezés tárgyában 34 .
}

ian judicial review can be traced back to this Commission.

\section{Korrespondenz:}

Imre Képessy

Eötvös Loránd University

Faculty of Law and Political Sciences

Department of the History of Hungarian State and

Law

Egyetem tér 1-3, 1053 Budapest, Hungary

kepessy.imre@ajk.elte.hu

\section{Literatur:}

Az 1861. évi magyar Országgyúlés, 3 Bde. (Pest 1861). Judit BEKE-MARTOS, Állami legitimációs eljárások és államfői jogkör 1867-1918 között (Budapest 2012).

Judit BEKE-MARTOS, Az Osztrák Császárság története és az államfői ceremonális hatalomlegitimáció hiánya, in: Századvég folyóirat 65 (Budapest 2012).

András BRAGYOVA, Az alkotmánybíráskodás elmélete (Budapest 1994).

Ferenc DEÁK, Adalék a magyar közjoghoz (Pest, 1865)

Ferenc ECKHART, Magyar alkotmány- és jogtörténet (Budapest, 1946).

Aurél KECSKEMÉTHY, Vázlatok egy év történetéből (Pest 1862).

Ágnes KenYERES (Hg.), Magyar Életrajzi Lexikon [http://www.mek.iif.hu/porta/szint/egyeb/lexikon/ eletrajz/html/] (2000, retrieved on: 15. 1. 2013).

Manó KónYI (Hg.), Deák Ferencz összes beszédei (Budapest 1886).

István KUKORELL (Hg.), Alkotmányjog, Bd. I (Budapest 2007).

Stefan LIPPERT, Felix Fürst zu Schwarzenberg. Eine politische Biographie (Stuttgart 1998).

Barna MeZEy (Hg.), Magyar alkotmánytörténet (Budapest. 2003).

Barna MezeY, Horváth Boldizsár az országbírói értekezleten, in: Jogtörténeti Szemle (2005/3).

Barna MEZEY, Horváth Boldizsár az 1861. évi országgyülésben, in: Jogtörténeti Szemle (2007/1).

Barna MEZEY (Hg.), Magyar jogtörténet (Budapest 2007).

Péter Paczolay (Hg.), Alkotmánybíráskodásalkotmányértelmezés (Budapest 1995). 
György RÁTH, Az országbírói értekezlet a törvénykezés tárgyában, 2 Bde. (Pest 1861).

Emil RÉCSI, Magyarország közjoga 1848-ig s mint az 1848-ban fennállott (Buda-Pest 1861).

László SóLYOM, Az alkotmánybíráskodás kezdetei Magyarországon (Budapest 2001).

László SóLYOM, Az alkotmánybíráskodás tizedik évfodulójára, in: Tíz éves az Alkotmánybíróság. Tudományos-szakmai konferencia (Budapest 2000).

János SuHAYDA, Magyarország közjoga (Pest 1861).
György SzABAD, Forradalom és kiegyezés válaszútján (Budapest 1967).

András SZABÓ, Jogállami forradalom és a büntetőjog alkotmányos legitimitása, in: Büntetőjog alkotmányossága (2000) 11-28.

Tamás M. TARJÁN, Nagy Lajos király kihirdeti az ösiség törvényét.

[http://www.rubicon.hu/magyar/oldalak/1351_dec ember_11_nagy_lajos_kiraly_kihirdeti_az_osiseg_ torvenyet/] (retrieved on: 15. 1. 2013) 